\title{
MODEL OPTIMALISASI DAYA SAING DAN SINERGIVITAS KINERJA UMKM DI JEPARA
}

\author{
Sarwido, Dwi Retno Sulistyawati \\ Sekolah Tinggi Teknologi dan Desain Nahdlatul Ulama Jepara \\ sarwido@ymail.com, retno.se15@yahoo.co.id
}

\begin{abstract}
Handling this issue for SMEs remains piecemeal and not comprehensive, comprehensive and simultaneous. Lack of coordination between agencies related to SME development led to many SMEs entangled bad credit and even go out of business. While the existence of SMEs is very important in supporting the national economy and create jobs and prosperity. This study is based on the problems faced by SMEs over the years, both the problems associated with the condition of internal and external conditions, among others, field operations, processing, marketing, capital, human resources, technology, business climate or competition .

This research can generally be concluded that based on the results obtained support the hypothesis testing positive and significant that reinforce the concept that SME performance improvement can be achieved through internal factors, external factors, barriers to innovation and partnership capabilities. Although the magnitude of the effect is not the same but overall indicate a significant influence.
\end{abstract}

Keywords : Internal and External Factors, Capability, Obstacles, Performance of SMEs.

\section{PENDAHULUAN}

Peran UMKM telah terbukti sejak terjadinya krisis ekonomi tahun 1997, mampu bertahan dan eksis hingga saat ini. Menurut Sasono (2002) sekitar 64\% kelompok ekonomi rakyat bergerak dalam Industri Kecil dan Menengah (IKM) dari total 200.000 lebih jenis usaha yang dapat bertahan. Pengembangan sektor UMKM tidak dapat dilakukan secara parsial, namun memerlukan pendekatan yang workable yang simultan dari seluruh unsur. Pengembangan UMKM masih terkendala pengelolaan usaha yang masih tradisional, kualitas sumber daya manusia yang belum memadai, skala dan teknik produksi, kapabilitas inovasi yang masih rendah serta masih terbatasnya akses kepada lembaga keuangan, khususnya perbankan. Selain kapabilitas inovasi, hambatan kemitraan dengan pihak eksternal seperti BUMN menjadikan kinerja UMKM tidak optimal. Akibat ketidakjelasan koordinasi tersebut telah menyebabkan kredit macet dana kemitraan hingga akhir 2004 mencapai 26,96 \% atau Rp 535.75 milliar.

Melihat berbagai temuan empirik sebelumnya serta kondisi riil pengembangan UMKM maka sangat penting untuk menemukan model optimalisasi kinerja UMKM secara komprehensif yang mencakup faktor internal, faktor eksternal serta hambatan dalam menjalin kemitraan dengan BUMN. Penelitian yang komprehensif belum pernah dilakukan, karena selama ini lebih banyak bersifat parsial, yaitu bidang manajemen, keuangan dan sumber daya manusia. Dengan demikian penelitian ini masih relatif langka dan penting untuk dilakukan untuk memberikan rekomendasi kepada para stakeholder (Kementerian Koperasi UMKM dan Pengelolaan Pasar, perbankan nasional, Pemerintah Kabupaten Jepara, serta industri UMKM) dalam meningkatkan kinerja UMKM. Penelitian yang dilakukan terhadap 11 sentra industri berskala kecil dan menengah di Jepara melibatkan mahasiswa Teknik Industri, terutama yang mengambil mata kuliah manajemen usaha kecil dan menengah.

Model optimalisasi kinerja UMKM secara komprehensif yang mencakup faktor eksternal, faktor internal serta hambatan dalam menjalin kemitraan dengan BUMN. Dengan demikian penelitian ini masih relatif langka dan penting untuk dilakukan untuk memberikan rekomendasi kepada para stakeholder (Kementerian koperasi dan UMKM, Bank Rakyat 
Indonesia, perbankan nasional, pemerintah kabupaten Jepara, LSM, perguruan tinggi serta industri UMKM) dalam meningkatkan kinerja UMKM.

Berdasarkan latar belakang, maka dapat dirumuskan masalah penelitian, yaitu bagaimana model optimalisasi daya saing dan sinergivitas kinerja UMKM di Jepara. Kemudian pertanyaan penelitian (question research) dalam penelitian ini adalah :

1. Bagaimana pengaruh faktor internal terhadap kinerja UMKM di Jepara?

2. Bagaimana pengaruh faktor eksternal terhadap kinerja UMKM di Jepara?

3. Bagaimana pengaruh kapabilitas inovasi terhadap kinerja UMKM di Jepara?

4. Bagaimana pengaruh hambatan kemitraan terhadap kinerjaUMKM di Jepara?

\section{LANDASAN TEORI}

\section{A. Definisi UMKM}

Di dalam UU No. 9 Tahun 1995, ditetapkan bahwa Usaha Kecil adalah suatu unit usaha yang meniliki aset neto (tidak termasuk tanah dan bangunan) yang tidak melebihi Rp 200 juta, atau penjualan per tahun tidak lebih besar dari Rp 1 miliar. Sedangkan menurut Inpres No. 10 Tahun 1999 tersebut, Usaha Menengah adalah suatu unit usaha dengan nilai aset neto (di luar tanah dan gedung) antara Rp 200 juta hingga Rp 10 miliar, diatas itu adalah Usaha Besar. Sedangkan menurut BPS (2000) Usaha Kecil adalah unit usaha dengan jumlah pekerja kurang dari 20 orang. Untuk selanjutnya dalam penelitian ini menggunakan definisi dari BPS. Sektor usaha pada UMKM dibedakan menjadi lima sektor usaha (BPS, 2000) yakni: sektor Pertambangan Rakyat dan Penggalian, Listrik non PLN dan Konstruksi, Industri Kecil dan Kerajinan Rumah Tangga, Perdagangan Besar, Eceran dan Rumah Makan serta Jasa Akomodasi, Angkutan dan Komunikasi, Lembaga Keuangan, Real Estate, Usaha Persewaan dan Jasa-jasa.

\section{B. Faktor-faktor Penentu Kapabilitas Inovasi}

\section{Ukuran Perusahaan.}

Variabel ukuran perusahaan dimasukkan dalam pengujian karena pada beberapa penelitian terdahulu ditemukan bahwa variabel ukuran perusahaan berpengaruh signifikan terhadap inovasi yang terjadi dalam perusahaan. Baldwin el al.,(1999), dalam penelitiannya menemukan bahwa perusahaan yang lebih besar lebih inovatif dibandingkan dengan perusahaan yang lebih kecil, karena memiliki kemudahan lebih pada akses pembiayaan, dapat menyebarkan biaya tetap inovsi pada volume penjualan yang lebih besar, manfaat yang diperoleh dari economies of scale, dan saling melengkapinya (complementarities) antara Riset dan Pengembangan dengan aktivitas-aktivitas yang lain dalam perusahaan.

2. Waktu

Dimensi waktu menjadi faktor yang penting untuk dipertimbangkan dalam proses membangun kapabilitas inovasi. Dengan terjadinya perbedaan proses pengembangan sumberdaya/area dalam perusahaan, maka faktor lama (pengalaman) beroperasi perusahaan diajukan peneliti untuk mengidentifikasi penyebab perbedaan proses membangun kapabilitas inovasi. Faktor lama beroperasi perusahaan didalam penelitian ini merujuk pada lamanya operasional perusahaan mulai berdirinya perusahaan sampai penelitian ini dilakukan dalam besaran tahun. Tidak adanya acuan yang pasti tentang bagaimana mengkategorikan perusahaan berdasarkan lama tahun beroperasinya, menyebabkan peneliti kesulitan untuk menentukan dasar pengkategoriannya.

3. Riset dan Pengembangan

Pemilihan faktor Riset dan Pengembangan didasarkan pada keyakinan banyak peneliti sebagai faktor yang berperan besar dalam meningkatkan kemampuan inovasi suatu perusahaan. Dukungan teoritis dan empiris yang cukup menyebabkan faktor Riset dan Pengembangan diajukan sebagai satu dari beberapa faktor penelitian. 
Berdasarkan observasi peneliti pada oyek penelitian, pada umumnya UMKM di Jepara tidak mempunyai divisi Riset dan Pengembangan. Meskipun demikian, bukan berarti pengelola UMKM tersebut tidak melakukan proses riset dan pengembangan untuk menghasilkan produk baru. Tanpa mereka sadari mereka telah melakukan proses riset dan pengembangan, yaitu dengan menyisihkan waktu dan sebagian dana dari penjualan untuk usaha-usaha pengembangan produk, pengamatan terhadap trend produk terbaru yang menjadi selera pasar, dan bekerjasama dengan pengelola UMKM yang lain untuk meningkatkan kemampuan inovasi.

4. Kapabilitas Sumber Daya Manusia

Inovasi mengkin merupakan kunci kesuksesan organisasi, akan tetapi tenaga kerja yang mempunyai skill yang tinggi merupakan faktor yang penting untuk inovasi (Baldwin,1999). Program pelatihan adalah metoda utama yang digunakan untuk meningkatkan skill tenaga kerja. Survey yang dilakukan Baldwin et al., (2009) terhadap perusahaan skala kecil dan menengah yang sedang tumbuh (Growing Small and Medium Enterprises) menunjukkan bahwa kehalian tenaga kerja (skill labour) merupakan kontributor terpenting untuk pertumbuhan perusahaan. Hal ini didasarkan pada temuan penelitian, bahwa sekitar 52\% perusahaan skala kecil dan menengah yang diteliti melaksanakan program pelatihan untuk meningkatkan sumber daya manusianya, 36\% diantaranya menggunakan program pelatihan formal.

5. Interaksi dan Komunikasi dengan Pihak Luar

Inovasi akan muncul apabila terjadi interaksi dan komunikasi yang intensif antara perusahaan dengan lingkungannya (Sarens, 1987; Roertson dan Gatignon 1987 dalam Slappendel, 1996). Interaksi dan komunikasi dengan lingkungan eksternal merupakan bentuk interaksi dan komunikasi perusahaan dengan konsumen, supplier, pesaing, institusi R\&D eksternal dan Asosiasi Industri (Romijn et. al., 2001).

Interaksi dengan konsumen akan memberikan kontribusi terhadap inovasi dengan membangkitkan permintaan (Marquiz; Utterback, 1982 dalam Slppendel, 1996). Kontribusi konsumen terhadap inovasi akan tergantung pada pengalaman mereka dan mungkin berbeda antar industri (Crocombe et al., 1991) dan antar negara (Parkinson, 1984). Supplier dapat menjadi sumber yang penting untuk inovasi yaitu dengan memberikan pengetahuan tentang ide-ide yang baru (Utterback, 1982) dan memberikan dukungan untuk kesuksesan implementasinya.

6. Penggunaan Teknologi

Peran teknologi yang sedemikian penting dalam suatu perusahaan berimplikasi pada kebutuhan untuk mengembangkan strategi teknologi dalam perusahaan. Burgelman, et al., (2006) menyatakan bahwa teknologi adalah sumber daya yang penting dalam organisasi yang perlu dikelola dengan baik, karena teknologi merupakan fungsi bisnis yang mendasar. Teknologi akan dapat membantu perusahaan untuk mendapatkan kompetensi pembeda (distinctive competence) yang memungkinkan perusahaan untuk menghasilkan produk yang lebih baik dari pesaingnya (Tidd, et el., 2007), sedangkan teknologi yang modern akan membawa peningkatan kualitas produk, pengembangan produk baru, produktivitas, dan efisiensi (Chowdhury, 2010).

7. Kapabilitas Pemasaran

Inovasi produk ataupun pelayanan tidak akan berarti banyak apabila tidak mencapai kesuksesan secara komersial (Byrd, 2007). Perusahaan haruslah mengembangkan kemampuannya untuk memasarkan produk atau pelayanan yang baru tersebut. Baldwin dan Johnson (2009) dalam penelitiannya di Canada menemukan bahwa perusahaan skala kecil dan menengah akan menjadi lebih inovatif apabila memberikan penekanan yang lebih besar pada pengembangan kapabilitas pemasaran, finansial, produksi dan sumber daya manusia. Kapabilitas 
pemasaran dalam penelitian ini merujuk pada kemampuan perusahaan untuk mengembangkan berbagai aspek yang terkait dengan pemasaran produk, meliputi: jaringan distribusi dan promosi.

8. Pengembangan Produk Baru

Terdapat bukti kuat yang menyatakan bahwa meluncurkan produk baru ke pasar sangatlah penting untuk menciptakan keunggulan kompetitif. Untuk mencapai kesuksesan produk baru, perusahaan harus selalu memberikan respon terhadap perubahan kebutuhan konsumen dan pergerakan para pesaingnya. Chase et al., (2006) menyatakan, karena peningkatan jumlah produk baru dan teknologi proses yang baru, sementara siklus hidup produk dan model produk semakin lama semakin pendek, maka perusahaan harus meningkatkan proyek pengembangan produk baru yang lebih besar daripada sebelumnya, dan penggunaan sumber daya yang lebih efisien pada masing-masing proyek.

9. Kapabilitas Produksi dan Operasi

Kapabilitas produksi dan operasi dalam penelitian ini didefinisikan sebagai kemampuan suatu organisasi untuk melakukan peningkatan efisiensi dan keefektifan didalam proses produksi/operasinya, meliputi: efisiensi bahan, kontrol kualitas, dan perencanaan dan penjadwalan dalam proses produksi. Pengembangan kapabilitas proses produksi terdiri dari tiga tahap yaitu pre-production, production, dan postproduction (Vuppalapati et al., 1993; Leonard dan Sasser,1982). Tahap pertama adalah tahap sebelum proses produksi (pre-production) meliputi tahap penerapan sistem desain yang berkualitas. Tahap kedua adalah tahap proses produksi (production). Pada tahap ini yang diperhatikan adalah jaminan kualitas produk. Salah satu cara yang dapat digunakan adalah proses pengawasan statistik, termasuk efisiensi penggunaan bahan, dan standarisasi produk. Tahan terakhir postproduction, adalah tahap pengawasan kualitas setelah proses produksi.

\section{Faktor-Faktor Yang Menghambat Proses Aliansi (Kemitraan)}

Aliansi strategik merupakan sarana bagi perusahaan untuk menginternalisasi kompetensi atau transfer knowledge dari perusahaan partner. Transfer knowledge tergantung pada bagaimana mudahnya knowledge dapat dipindahkan, diinterpretasikan dan diserap (Hamel et al., 1989). Dalam proses ini Hedlund dan Zander (dalam Simonin, 1999) menekankan perlunya mempertimbangkan dampak yang lebih tajam terhadap knowledge, khususnya ambiguitas, yaitu perlawanan terhadap komunikasi yang jelas, keberadaan di dalam konteks, dan yang bersifat khusus. Reed dan DeFillippi (1990) menjelaskan bahwa ada rintangan/kendala yang kuat untuk memulai peniruan (imitation) dari ketidakmampuan pesaing untuk memahami kompetensi yang merupakan sumber keunggulan bersaing.

Ada beberapa faktor multiple yang menentukan tingkat ambiguitas transfer knowledge pada aliansi strategik. Faktor-faktor tersebut adalah: tacitness, aset yang bersifat khusus (specificity), kompleksitas, pengalaman , protectiveness, perbedaan budaya organisasional diantara partner. Reed dan DeFillippi (1990) mendefinisikan tacitness sebagai akumulasi yang tidak dapat dikodifikasi dan implisit pada keahlian, hasil pembelajaran melalui belajar (learning-by-doing). Tacit knowledge tidak dapat dikomunikasikan dan tidak dapat dibagi, sangat bersifat individu, berakar secara mendalam dan ada suatu keterlibatan individual dalam kontek yang khusus (Nonaka, dalam Simonin, 1999). Kekhususan (specificity) meliputi aset yang bersifat khusus pada biaya transaksi. Atribut-atribut tersebut merupakan indikator yang eksplisit pada tingkat harapan protectiveness bagi pengirim informasi berdasar knowledge. Perbedaan budaya partner antara lain meliputi perbedaan dalam budaya organisasional (Tyebjee, dalam Simonin,1999). Perbedaan budaya organisasional menunjukkan tingkat ketidaksamaan antara praktik bisnis partner, warisan institusional dan budaya 
organisasional. Killing (1982) juga menyatakan bahwa perbedaan organisasional mempengaruhi transfer knowledge.

\section{Kinerja Perusahaan (UMKM)}

Dimensi pertumbuhan dikenal sebagai ukuran kinerja yang paling penting, terutama pada perusahaan kecil (Tsai et al. 2006; Wiklund 2009) dan merupakan uji kinerja yang baik ditengah kondisi resesi ekonomi dan persaingan yang ketat (Swamidass dan Newell 1987). Pertumbuhan penjualan merupakan indikator kinerja yang sangat lazim dan telah menjadi konsensus sebagai ukuran pertumbuhan yang terbaik. Pertumbuhan penjualan dan pertumbuhan pangsa pasar merupakan ukuran pertumbuhan yang baik. Pertumbuhan pangsa pasar dapat digunakan untuk mengukur efektivitas pasar. Pertumbuhan laba juga merupakan indikator pertumbuhan yang penting dan dapat mencerminkan kinerja keuangan perusahaan. Dimensi kemampulabaan untuk mengetahui kemampuan perusahaan dalam menghasilkan laba atau seberapa jauh perusahaan dapat dikelola secara efektif.

\section{E. Kerangka Pemikiran Teoritis}

Kerangka pemikiran teoritis ini menyajikan suatu pengembangan model hubungan kinerja UMKM yang dipengaruhi oleh faktor Internal, faktor eksternal, kapabilitas inovasi dan hambatan Kemitraan

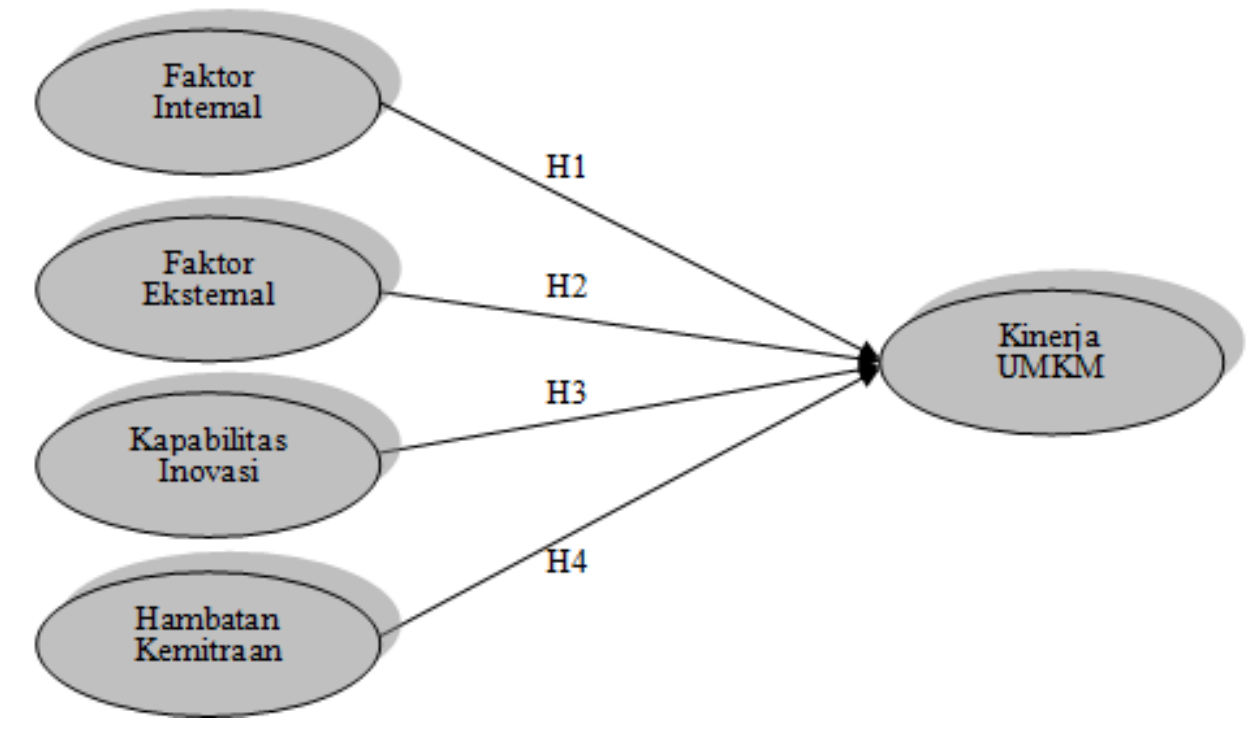

Gambar 1. Model Empirik Optimalisasi Daya Saing dan Sinergivitas Kinerja UMKM di Jepara

\section{F. Hipotesis}

Berdasarkan kerangka pemikiran teoritis model empirik optimalisasi daya saing dan sinergivitas kinerja UMKM di Jepara, maka hipotesis yang diajukan adalah sebagai berikut:

H1. Faktor internal berpengaruh positif dan signifikan terhadap kinerja UMKM di Jepara

H2. Faktor eksternal berpengaruh positif dan signifikan terhadap kinerja UMKM di Jepara

H3. Kapabilitas inovasi berpengaruh positif dan signifikan terhadap kinerja UMKM di Jepara

H4. Hambatan kemitraan BUMN berpengaruh positif dan signifikan terhadap kinerja UMKM di Jepara 


\section{G. Tujuan Penelitian}

1. Mengidentifikasi dan menganalisis kondisi internal, kondisi eksternal, kapabilitas inovasi, hambatan kemitraan terhadap kinerja UMKM

2. Membuat model optimalisasi dan sinergivitas kinerja UMKM sebagai pedoman optimalisasi kinerja UMKM di Jepara.

\section{H. Manfaat Penelitian}

Hasil penelitian ini diharapkan dapat bermanfaat secara praktis, khususnya dalam membangun kerangka pikir dan perumusan kebijakan dalam hal optimalisasi kinerja UMKM. Diharapkan penelitian ini menjadi salah satu pendukung dalam penyediaan fasilitas riset pengembangan beberapa mahasiswa S-1 di lingkungan Program Studi Teknik Industri yang bermanfaat untuk pemberdayaan kinerja UMKM, khususnya dalam hal peningkatan inovasi UMKM.

\section{METODOLOGI PENELITIAN}

Ruang lingkup studi mencakup wilayah kecamatan Welahan, Mayong, Kalinyamatan, Pecangaan, Tahunan, Jepara, Mlonggo, Bangsri. Pemilihan wilayah studi ini berdasarkan banyaknya industri UMKM di wilayah Kabupaten Jepara. Variabel-variabel yang dikaji dalam penelitian mencakup faktor internal, faktor eksternal, kapabilitas inovasi, hambatan kemitraan yang nantinya mempengaruhi pencapaian kinerja UMKM di Jepara. Penelitian dilakukan dengan metode survei, baik melalui wawancara yang mendalam dengan berbagai pihak stakeholders dalam pengembangan UMKM maupun menggunakan instrumen kuesioner.

Populasi dalam penelitian ini adalah seluruh UMKM di Jepara sebanyak 7.842 perusahaan. Kerangka sampel penelitian ini adalah Usaha Mikro Kecil dan Menengah (UMKM) yang berada di Jepara. Responden dalam penelitian ini adalah pemilik atau pengelola UMKM. Berdasarkan beberapa pedoman di dalam menentukan besarnya sampel, maka besarnya sampel yang digunakan dalam penelitian ini sebanyak 100 responden. Pengambilan sampel menggunakan nonprobabilitas (secara tidak acak) dengan metode purposive sampling yang berdasarkan pertimbangan. Pemilihan sampel nonprobabilitas berarti elemen-elemen populasi tidak mempunyai kesempatan yang sama untuk terpilih menjadi sampel. Sedangkan metode purposisive sampling yang ditujukan kepada pengelola atau pemilik UMKM dengan memertimbangkan UMKM yang sudah beroperasi minimal lima tahun. Responden dalam penelitian ini adalah para pemilik /pelaku UMKM. Masingmasing responden akan dilakukan wawancara serta pengisian kuesioner.

\section{HASIL DAN PEMBAHASAN}

\section{A. Karakteristik Responden}

Karakteristik responden dalam studi ini meliputi umur, pendidikan, jenis kelamin pemilik UMKM di Jepara.

Tabel 1. Diskripsi Umur Responden

\begin{tabular}{rlcc}
\hline No & \multicolumn{1}{c}{ Keterangan } & Frekuensi & \% \\
\hline 1 & Antara 20 s/d 29 tahun & 13 & $13 \%$ \\
2 & Antara 30 s/d 39 tahun & 19 & $19 \%$ \\
3 & Antara 40 s/d 49 tahun & 45 & $45 \%$ \\
3 & $\geq 50$ tahun & 23 & $23 \%$ \\
\hline \multicolumn{2}{r}{ Total } & 100 & $100 \%$ \\
\hline
\end{tabular}


Tabel 2. Diskripsi Jenis Kelamin Responden

\begin{tabular}{cllcc}
\hline No & & Keterangan & Frekuensi & \% \\
\hline 1 & Pria & & 81 & $81 \%$ \\
2 & Wanita & & 19 & $19 \%$ \\
\hline & & Total & 62 & $100 \%$ \\
\hline
\end{tabular}

Tabel 3. Diskripsi Pendidikan Responden

\begin{tabular}{rlccc}
\hline No & & Keterangan & Frekuensi & \% \\
\hline 1 & Sarjana & & 11 & $11 \%$ \\
2 & SLTA & & 52 & $52 \%$ \\
3 & SLTP & & 22 & $22 \%$ \\
4 & SD & & 15 & $15 \%$ \\
\hline & & Total & 100 & $100 \%$ \\
\hline
\end{tabular}

Berdasarkan karakteristik responden berdasarkan umur, responden dengan umur paling banyak umur antara 40 sampai dengan 49 tahun yaitu sejumlah 45 orang (45\%). Berdasarkan tingkat pendidikan, responden dengan tingkat pendidikan sampai dengan lulus SLTA paling banyak yaitu sejumlah 52 orang (52\%). Berdasarkan jenis kelamin, responden dengan jenis kelamin pria paling banyak yaitu sejumlah 81 orang (81\%).

B. Hasil Analisis PLS

1. Hasil Outer Model

Tabel 4. Hasil Uji Validitas dan Reliabilitas Indikator Variabel Faktor Internal

\begin{tabular}{lcccc}
\hline Indikator & \multicolumn{2}{c}{ Uji Validitas } & Composite Reliability \\
\cline { 2 - 4 } & Loading & T-Statistic & Ket & \\
\hline X1.1 & 0,894 & 27,400 & valid & 0.935 \\
X1.2 & 0,899 & 36,628 & valid & \\
X1.3 & 0,888 & 25,275 & valid & \\
X1.4 & 0,855 & 13,617 & valid & \\
\hline
\end{tabular}

Tabel 5. Hasil Uji Validitas dan Reliabilitas Indikator Variabel Faktor Eksternal

\begin{tabular}{lcccc}
\hline Indikator & \multicolumn{3}{c}{ Uji Validitas } & Composite Reliability \\
\cline { 2 - 4 } & Loading & T-Statistic & Ket & \\
\hline X2.1 & 0,833 & 19,079 & valid & 0.934 \\
X2.2 & 0,861 & 22,838 & valid & \\
X2.3 & 0,820 & 10,565 & valid & \\
X2.4 & 0,886 & 29,878 & valid & \\
X2.5 & 0,894 & 26,702 & valid & \\
\hline
\end{tabular}

Tabel 6. Hasil Uji Validitas dan Reliabilitas Indikator Variabel Kapabilitas Inovasi

\begin{tabular}{lcccc}
\hline Indikator & \multicolumn{3}{c}{ Uji Validitas } & Composite Reliability \\
\cline { 2 - 4 } & Loading & T-Statistic & Ket & \\
\hline X3.1 & 0,935 & 32,899 & valid & 0.939 \\
X3.2 & 0,886 & 31,537 & valid & \\
X3.3 & 0,894 & 28,797 & valid & \\
\hline
\end{tabular}


Tabel 7. Hasil Uji Validitas dan Reliabilitas Indikator Variabel Hambatan Kemitraan

\begin{tabular}{lcccc}
\hline Indikator & \multicolumn{3}{c}{ Uji Validitas } & Composite Reliability \\
\cline { 2 - 4 } & Loading & T-Statistic & Ket & \\
\hline X4.1 & 0,853 & 18,454 & valid & 0.911 \\
X4.2 & 0,893 & 24,594 & valid & \\
X4.3 & 0,850 & 16,874 & valid & \\
X4.4 & 0,812 & 10,067 & valid & \\
X4.5 & 0,608 & 4,088 & valid & \\
X4.6 & 0,724 & 9,389 & valid & \\
\hline
\end{tabular}

Tabel 8. Hasil Uji Validitas dan Reliabilitas Indikator Variabel Kinerja UMKM

\begin{tabular}{lcccc}
\hline Indikator & \multicolumn{3}{c}{ Uji Validitas } & Composite Reliability \\
\cline { 2 - 4 } & Loading & T-Statistic & Ket & \\
\hline Y1.1 & 0,916 & 19,120 & valid & 0.895 \\
Y1.2 & 0,883 & 17,461 & valid & \\
\hline
\end{tabular}

Berdasarkan hasil outer mode,l hasil dari uji convergent validity indikator faktor internal, faktor eksternal, kapabilitas inovasi, hambatan kemitraan dan kinerja UMKM memiliki nilai loading factor seluruh indikator lebih dari 0,5 dan nilai Tstatistik seluruh indikator lebih besar dari T-tabel yaitu sebesar 1,660, sehingga seluruh indikator valid.

Uji discriminant validity dari model pengukuran dengan reflektif indikator dinilai dengan membandingkan nilai square root of average variance extracted (AVE) setiap konstruk dengan korelasi antara konstruk dengan konstruk lainnya dalam model. Menurut Fornell and Larcker (1981), nilai AVE harus lebih besar dari 0,5. Berdasarkan perhitungan PLS, nilai AVE variabel faktor internal sebesar 0.782, faktor eksternal sebesar 0.738, kapabilitas inovasi sebesar 0.837, hambatan kemitraan sebesar 0.634 dan kinerja UMKM sebesar 0,810 lebih besar dari 0,5. Jadi dapat disimpulkan bahwa konstruk kinerja UMKM dalam model yang diestimasi memenuhi kriteria discriminant validity.

Berdasarkan uji composite reliability dari blok indikator yang mengukur konstruk, menunjukkan hasil yang memuaskan yaitu faktor internal sebesar 0.935, faktor eksternal sebesar 0.934, kapabilitas inovasisi sebesar 0.939, hambatan kemitraan sebesar 0.911, dan kinerja UMKM sebesar 0.895 artinya bahwa semua konstruk dapat memberikan hasil yang relatif sama bila dilakukan pengukuran kembali pada subyek yang sama.

Tabel 9. Hasil $R$ Square

\begin{tabular}{lc}
\hline \multicolumn{1}{c}{ Variabel } & R-square \\
\hline Faktor Internal & \\
Faktor Eksternal & \\
Kapabilitas Inovasi & \\
Hambatan Kemitraan & \\
Kinerja UMKM & 0,947 \\
\hline
\end{tabular}

Berdasarkan Tabel Hasil $R$ Square dapat diketahui bahwa nilai $R$-square kinerja UMKM sebesar 0.947, artinya bahwa model regresi memiliki tingkat goodness-fit yang sangat baik, artinya bahwa variabilitas kinerja UMKM dapat dijelaskan oleh variasi keempat variabel yaitu faktor internal, faktor eksternal, kapabilitas inovasi dan 
hambatan kemitraan sebesar 94,7 \% sisanya sebesar 5,3 \% dijelaskan oleh variabel lain di luar model.

\section{Hasil Inner Model (Model Struktural)}

Tabel 10. Hasil Pengujian Hipotesis

\begin{tabular}{ccccc}
\hline Hipotesis & $\begin{array}{c}\text { Pengaruh Antar } \\
\text { Variabel }\end{array}$ & $\begin{array}{c}\text { Koefisien } \\
\text { Estimate }\end{array}$ & T-Statistik & Keputusan \\
\hline 1 & $\begin{array}{c}\text { Faktor Internal }> \\
\text { Kinerja UMKM }\end{array}$ & 1,449 & 5,116 & Signifikan \\
2 & $\begin{array}{c}\text { Faktor Eksternal }> \\
\text { Kinerja UMKM }\end{array}$ & 1,264 & 13,119 & Signifikan \\
3 & $\begin{array}{c}\text { Kapabilitas Inovasi }> \\
\text { Kinerja UMKM }\end{array}$ & $-0,468$ & 2,352 & Signifikan \\
4 & $\begin{array}{c}\text { Hambatan Kemitraan } \\
\text { / Kinerja UMKM }\end{array}$ & $-1,242$ & 3,975 & Signifikan \\
\hline
\end{tabular}

Keterangan : $\mathrm{t}(0,05,99)=1,660$

\section{Hasil Pengujian Hipotesis dan Pembahasan}

H1 : Faktor internal berpengaruh positif dan signifikan terhadap kinerja UMKM

Hipotesis pertama yang berbunyi faktor internal berpengaruh positif dan signifikan terhadap kinerja UMKM. Berdasarkan hasil perhitungan uji PLS yang menguji hipotesis pertama yaitu pengaruh faktor internal terhadap kinerja UMKM diperoleh hasil uji nilai T-statistik sebesar 5,116 dan T-tabel sebesar 1,660. Jadi dapat disimpulkan bahwa terdapat pengaruh positif dan signifikan dari variabel faktor internal terhadap kinerja UMKM, artinya bahwa semakin kuat faktor internal maka semakin tinggi kinerja UMKM. Dengan kata lain semakin kuat faktor internal, maka akan dapat memberikan dampak yang sangat positif terhadap peningkatan kinerja UMKM. Dengan demikian, maka hipotesis pertama terbukti dan diterima.

Dalam penelitian ini faktor-faktor internal meliputi keberadaan intitusi riset dan pengembangan, kapabilitas sumber daya manusia atau tenaga kerja, investasi pada pelatihan dan pengembangan sumber daya manusia, dan penggunaan teknologi terbukti merupakan faktor-faktor yang berperan dalam meningkatkan kinerja UMKM.

Pengembangan produk baru memiliki peran yang dominan dalam meningkatkan daya saing pada industri berskala kecil. Pemilihan riset dan pengembangan sebagai faktor internal penentu kinerja UMKM didasarkan pada keyakinan banyak peneliti sebagai faktor yang berperan besar dalam meningkatkan kemampuan inovasi. Hasil penelitian ini mengindikasikan bahwa para pelaku UMKM memandang semakin pentingnya keberadaan institusi riset dan pengembangan. Hal ini diikuti dengan usaha mereka dalam meningkatkan kinerja UMKM yang meliputi semakin rutinnya usaha promosi produk, senantiasa melakukan hal-hal baru yang berhubungan dengan pengembangan produk, serta dengan semakin meningkatnya kemampuan dalam menghasikan produk yang terstandarisasi.

Penelitian ini juga menjelaskan bahwa untuk mencapai kinerja UMKM yang optimal diperlukan usaha meningkatkan faktor internal yang lain yaitu kapabilitas sumberdaya manusia. Kapabilitas pengembangan sumberdaya manusia merupakan kemampuan suatu organisasi untuk melakukan pengembangan dan 
peningkatan kemampuan teknis dan manajerial sumberdaya manusianya. Usaha tersebut dilakukan dengan cara selalu menselaraskan antara kemampuan dan keahlian karyawan dengan tugas mereka melalui program pelatihan dan pengembangan SDM. Hal tersebut penting dilakukan mengingat tenaga kerja yang mempunyai skill yang tinggi merupakan faktor penting untuk inovasi (Baldwin, 1999). Program pelatihan adalah metoda utama yang digunakan untuk meningkatkan skill karyawan. Survey yang dilakukan Baldwin et al., (1995) menunjukkann bahwa keahlian tenaga kerja (skill labour) merupakan kontributor terpenting untuk pertumbuhan perusahaan.

Dari jawaban responden terhadap pertanyaan terbuka yang disampaikan peneliti terungkap bahwa beberapa kendala dirasakan oleh UMKM dalam usaha riset dan pengembangan antara lain adanya keterbatasan dana dan SDM. Hal tersebut bisa dimaklumi mengingat untuk dapat memiliki bagian R \& D memang diperlukan dana yang cukup besar dan SDM yang memadai. Berdasarkan observasi peneliti pada obyek penelitian terdahulu, pada umumnya UMKM di Jepara banyak yang tidak mempunyai divisi Riset dan Pengembangan. Meskipun demikian, bukan berarti pengelola UKM tersebut tidak melakukan proses riset dan pengembangan untuk menghasilkan produk baru. Tanpa mereka sadari mereka telah melakukan proses riset dan pengembangan, yaitu dengan menyisihkan waktu dan sebagian dana dari penjualan untuk usaha-usaha pengembangan produk, pengamatan terhadap trend produk terbaru yang menjadi selera pasar, dan bekerjasama dengan pengelola UMKM yang lain untuk meningkatkan kemampuan inovasi (Rahmani \& Siyamtinah, 2009) . Untuk kemampuan dan keahlian karyawan, pihak pengelola UKM sebagian besar memandang hal tersebut sangat berpengaruh dalam meningkatkan kinerja usaha mereka.

\section{H2 : Faktor eksternal berpengaruh positif dan signifikan terhadap kinerja UMKM}

Hipotesis kedua yang berbunyi faktor internal berpengaruh positif dan signifikan terhadap kinerja UMKM. Berdasarkan hasil perhitungan uji PLS yang menguji hipotesis kedua yaitu pengaruh faktor eksternal terhadap kinerja UMKM diperoleh hasil uji nilai T-statistik sebesar 13,119dan T-tabel sebesar 1,660. Jadi dapat disimpulkan bahwa terdapat pengaruh positif dan signifikan dari variabel faktor eksternal terhadap kinerja UMKM, artinya bahwa semakin baik pengelolaan faktor eksternal maka semakin meningkatkan kinerja UMKM. Dengan kata lain semakin baik pengelolaan faktor eksternal, maka akan dapat memberikan dampak yang sangat positif terhadap peningkatan kinerja UMKM. Dengan demikian, maka hipotesis kedua terbukti dan diterima.

Dalam penelitian ini faktor-faktor eksternal meliputi adanya dukungan finansial dari pemerintah/perbankan/BUMN, adanya dukungan dana pemerintah untuk riset dan pengembangan, penggunaan intellectual property right, interaksi dan komunikasi dengan pihak luar, dan situasi persaingan.

Hasil penelitian ini mendukung pendapat Baldwin et al (2000) yang menyatakan faktor-faktor eksternal seperti dukungan finansial dan dukungan riset dan pengembangan dari pihak luar, penggunaan intellectual property rights, serta interaksi dengan pihak luar, merupakan faktor-faktor yang berperan dalam meningkatkan aktivitas inovasi. Dalam penelitian ini, para pelaku UMKM memandang dukungan pemerintah dan pihak perbankan merupakan hal yang penting guna meningkatkan kinerja UMKM mereka.

Inovasi akan muncul apabila terjadi interaksi dan komunikasi yang intensif antara perusahaan dengan lingkungannya (Sarens, 1987; Roertson dan Gatingnon, 1987 dalam Slappendel, 1996). Organisasi yang lebih terbuka dan berkemauan untuk menerima dan bahkan mencari ide-ide baru dari lingkungan eksternalnya, 
menjadikan organisasi tersebut lebih inovatif. Interaksi dan komunikasi dengan lingkungan eksternal merupakan bentuk interaksi dan komunikasi perusahaan dengan konsumen, supplier, pesaing, institusi R \& D eksternal dan Asosiasi Industri (Romjin et.al., 1999). Interaksi dengan konsumen akan memberikan kontribusi terhadap inovasi dengan meningkatnya permintaan. Kontribusi konsumen terhadap inovasi akan tergantung pada pengalaman mereka, dan berbeda antar industri maupun negara. Interaksi dengan supplier dapat menjadi sumber yang penting untuk inovasi yaitu dengan memberikan pengetahuan tentang ide-ide yang baru dan memberikan dukungan untuk kesuksesan implementasinya. Ettlie, dalam Siyamtinah (2007) mengemukakan bahwa sifat hubungan antara perusahaan dan supplier merupakan faktor yang paling berpengaruh terhadap kesuksesan ataupun kegagalan implementasi dari suatu sistem inovasi. Selain membangun hubungan baik dengan pemasok (supplier) maupun dengan konsumen, interaksi dengan pesaing dalam bentuk persaingan yang sehat antar pesaing akan meningkatkan aktivitas inovasi perusahaan (Crocombe, 2001).

Dari jawaban responden nampak bahwa kendala yang banyak dirasakan pihak UMKM dalam mendapatkan dana dari pemerintah/perbankan adalah kurangnya akses untuk mendapatkan dana tersebut, tidak adanya jaminan, serta persyaratan yang rumit. Sedangkan untuk dukungan pemerintah dalam riset dan pengembangan diharapkan bisa dalam bentuk penyuluhan (aspek SDM), promosi (aspek pemasaran), serta modal (aspek keuangan). Sementara itu, sebagian besar responden juga mengungkapkan ketidak pahaman mereka dalam mengurus hak paten.

\section{H3 : Kapabilitas inovasi berpengaruh positif dan signifikan terhadap kinerja UMKM}

Hipotesis ketiga yang berbunyi kapabilitas inovasi berpengaruh positif dan signifikan terhadap kinerja UMKM. Berdasarkan hasil perhitungan uji PLS yang menguji hipotesis kedua yaitu pengaruh faktor eksternal terhadap kinerja UMKM diperoleh hasil uji nilai T-statistik sebesar 2,352 dan T-tabel sebesar 1,660. Jadi dapat disimpulkan bahwa terdapat pengaruh positif dan signifikan dari variabel kapabilitas inovasi terhadap kinerja UMKM, artinya bahwa semakin baik pengelolaan kapabilitas inovasi maka semakin meningkatkan kinerja UMKM. Dengan kata lain semakin baik pengelolaan kapabilitas inovasi, maka akan dapat memberikan dampak yang sangat positif terhadap peningkatan kinerja UMKM. Dengan demikian, maka hipotesis kedua terbukti dan diterima.

Dalam penelitian ini kapabilitas inovasi meliputi kapabilitas pemasaran, pengembangan produk baru, dan kapabilitas produksi dan operasi. Rahmani dan Siyamtinah (2009) menyatakan bahwa keragaman pola membangun kapabilitas inovasi tidak berdampak pada kinerja UMKM. Penelitian ini memberikan hasil yang berbeda, karena ternyata kapabilitas inovasi berpengaruh positif terhadap kinerja UMKM di Jepara. Lawless dan Anderson, dalam Rahmani (2004) berpendapat inovasi berpengaruh terhadap kinerja perusahaan, akan tetapi tergantung pada kompleksitas pasar yang dihadapi. Semakin kompleks kondisi pasar, maka semakin kuat pengaruh inovasi terhadap kinerja perusahaan. Penelitian Zahra dan Das (1993) dan Sharma dan Fisher (1997) menunjukkan inovasi memiliki pengaruh terhadap kinerja perusahaan. Terdapat perbedaan cara pandang antara penelitian dengan penelitian sebelumnya. Penelitian ini melihat inovasi dari sisi kemampuan UMKM dalam melakukan inovasi, atau dengan kata lain kapabilitas inovasinya. Sedangkan penelitian Rahmani dan Siyamtinah (2009) melihat inovasi dari perbedaan/keragaman pola membangun kapabilitas inovasinya. Sedangkan penelitian Rahmani dan Siyamtinah (2009) melihat inovasi dari perbedaan/keragaman pola membangun kapabilitas inovasinya. 
Kapabilitas produksi dan operasi dalam penelitian ini didefinisikan sebagai kemampuan suatu organisasi untuk melakukan peningkatan efisiensi dan keefektifan didalam proses produksi/operasinya, meliputi: efisiensi bahan, kontrol kualitas, dan perencanaan dan penjadwalan dalam proses produksi. Pengembangan kapabilitas proses produksi terdiri dari tiga tahap yaitu pre-production, production, dan post-production (Vuppalapati et al., 1993; Leonard dan Sasser,1982). Tahap pertama adalah tahap sebelum proses produksi (pre-production) meliputi tahap penerapan sistem desain yang berkualitas. Tahap kedua adalah tahap proses produksi (production). Pada tahap ini yang diperhatikan adalah jaminan kualitas produk. Salah satu cara yang dapat digunakan adalah proses pengawasan statistik, termasuk efisiensi penggunaan bahan, dan standarisasi produk. Tahan terakhir postproduction, adalah tahap pengawasan kualitas setelah proses produksi.

\section{H4 : Hambatan kemitraan berpengaruh positif dan signifikan terhadap kinerja UMKM}

Hipotesis keempat yang berbunyi hambatan kemitraan berpengaruh positif dan signifikan terhadap kinerja UMKM. Berdasarkan hasil perhitungan uji yang menguji hipotesis kedua yaitu pengaruh faktor eksternal terhadap kinerja UMKM diperoleh hasil uji nilai T-statistik sebesar 3,975 dan T-tabel sebesar 1,660. Jadi dapat disimpulkan bahwa terdapat pengaruh positif dan signifikan dari variabel hambatan kemitraan terhadap kinerja UMKM, artinya bahwa semakin baik pengelolaan hambatan kemitraan maka semakin meningkatkan kinerja UMKM. Dengan kata lain semakin baik pengelolaan hambatan kemitraan, maka akan dapat memberikan dampak yang sangat positif terhadap peningkatan kinerja UMKM. Dengan demikian, maka hipotesis kedua terbukti dan diterima.

Dalam penelitian ini hambatan kemitraan meliputi tacitness, specitificity, kompleksitas, pengalaman, protectiveness dan budaya organisasi. Aliansi strategik merupakan sarana bagi perusahaan untuk menginternalisasi kompetensi atau transfer knowledge dari perusahaan partner. Transfer knowledge tergantung pada bagaimana mudahnya knowledge dapat dipindahkan, diinterpretasikan dan diserap (Hamel et al., 1989). Dalam proses ini Hedlund dan Zander (dalam Simonin, 1999) menekankan perlunya mempertimbangkan dampak yang lebih tajam terhadap knowledge, khususnya ambiguitas, yaitu perlawanan terhadap komunikasi yang jelas, keberadaan di dalam konteks, dan yang bersifat khusus. Reed dan DeFillippi (1990) menjelaskan bahwa ada rintangan/kendala yang kuat untuk memulai peniruan (imitation) dari ketidakmampuan pesaing untuk memahami kompetensi yang merupakan sumber keunggulan bersaing.

Ada beberapa faktor multiple yang menentukan tingkat ambiguitas transfer knowledge pada aliansi strategik. Faktor-faktor tersebut adalah: tacitness, aset yang bersifat khusus (specificity), kompleksitas, pengalaman , protectiveness, perbedaan budaya organisasional diantara partner. Reed dan DeFillippi (1990) mendefinisikan tacitness sebagai akumulasi yang tidak dapat dikodifikasi dan implisit pada keahlian, hasil pembelajaran melalui belajar (learning-by-doing). Tacit knowledge tidak dapat dikomunikasikan dan tidak dapat dibagi, sangat bersifat individu, berakar secara mendalam dan ada suatu keterlibatan individual dalam kontek yang khusus (Nonaka, dalam Simonin, 1999). Kekhususan (specificity) meliputi aset yang bersifat khusus pada biaya transaksi. Atribut-atribut tersebut merupakan indikator yang eksplisit pada tingkat harapan protectiveness bagi pengirim informasi berdasar knowledge. Perbedaan budaya partner antara lain meliputi perbedaan dalam budaya organisasional (Tyebjee, dalam Simonin,1999). Perbedaan budaya organisasional menunjukkan tingkat ketidaksamaan antara praktik bisnis partner, warisan institusional dan budaya organisasional. Killing (1982) juga menyatakan bahwa perbedaan organisasional mempengaruhi transfer knowledge. 


\section{KESIMPULAN}

Penelitian ini secara umum dapat disimpulkan bahwa berdasarkan hasil pengujian hipotesis diperoleh dukungan positif dan signifikan yang memperkuat konsep yang menyatakan bahwa peningkatan kinerja UMKM dapat dicapai melalui faktor internal, faktor eksternal, kapabilitas inovasi dan hambatan kemitraan. Meskipun besarnya pengaruh tidak sama tetapi secara keseluruhan menunjukkan pengaruh yang signifikan. Berdasarkan hasil pengujian hipotesis dengan perhitungan PLS dapat ditarik simpulan hipotesis sebagai berikut :

1. Faktor internal berpengaruh positif dan signifikan terhadap kinerja UMKM. Hal ini membuktikan bahwa terdapat pengaruh positif dan signifikan dari variabel faktor internal terhadap kinerja UMKM, artinya bahwa semakin kuat faktor internal maka semakin tinggi kinerja UMKM.

2. Faktor eksternal berpengaruh positif dan signifikan terhadap kinerja UMKM. Hal ini membuktikan bahwa terdapat pengaruh positif dan signifikan dari variabel faktor eksternal terhadap kinerja UMKM, artinya bahwa semakin baik pengelolaan faktor eksternal maka semakin meningkatkan kinerja UMKM.

3. Kapabilitas inovasi berpengaruh positif dan signifikan terhadap kinerja UMKM. Hal ini membuktikan bahwa terdapat pengaruh positif dan signifikan dari variabel kapabilitas inovasi terhadap kinerja UMKM, artinya bahwa semakin baik pengelolaan kapabilitas inovasi maka semakin meningkatkan kinerja UMKM.

4. Hambatan kemitraan berpengaruh positif dan signifikan terhadap kinerja UMKM. Hal ini membuktikan bahwa terdapat pengaruh positif dan signifikan dari variabel hambatan kemitraan terhadap kinerja UMKM, artinya bahwa semakin baik pengelolaan hambatan kemitraan maka semakin meningkatkan kinerja UMKM.

\section{SARAN}

Bagi UMKM :

1. Sebaiknya melakukan usaha pengelolaan faktor intenal, faktor eksternal, kapabilitas inovasi dan hambatan kemitraan dengan sebaik-baiknya, karena hal tersebut terbukti akan mampu meningkatkan kinerja UMKM.

2. Meningkatnya kinerja UMKM, sebaiknya disikapi pihak UMKM sebagai cambuk untuk lebih memperbaiki performance UMKM. Fenomena tersebut bisa diartikan bahwa UMKM di Jepara terbukti mampu berkembang dengan baik dalam usahanya.

Bagi Pemerintah dan Perbankan :

1. Perlu adanya dukungan yang lebih besar dari pemerintah dan pihak perbankan dalam ikut mengembangkan UMKM, bukan hanya dukungan finansial namun juga dukungan keterampilan dan manajemen usaha.

2. Upaya menciptakan iklim usaha yang kondusif bagi UMKM perlu terus dilakukan mengingat posisi strategis UMKM sebagai penyedia lapangan kerja bagi masyarakat dan memiliki kontribusi yang tidak kecil dalam ikut memperkokoh perekonomian nasional terbukti mampu survive/bertahan dalam berbagai kondisi.

\section{DAFTAR PUSTAKA}

[1] Baldwin, John R. (2009), Innovation, Training and Succes, Working Paper Series, Micro-Economic Analysis Division Canada, No. 137.

[2] (2005), Innovation: The Key To Success in Small Firms, Working Paper Series, Micro-Economic Studies and Analysis Division, Statistics Canada and Canadian Institute for Advanced Research Economic Project Growth, No. 76. Hanel, Peter, and Sabourin, David (2010), Departements of Innonative Activity in Canadian Manufacturing Firm: The Role of Intellectual Property Right, Research Paper Series, Statistics Canada No. 11F0019MPE No. 122. 
[4] Biro Pusat Statistik (2009), Statistik Industri Perusahaan Manufaktur Skala Menengah dan Besar, Jakarta, Indonesia.

[5] (2010), Profil Usaha Kecil dan Menengah di Indonesia, Jakarta, Indonesia.

[6] Bleeke, J. dan D. Erns (2006),'The Way to Win in Cross-border Alliance”, Harvard Business Review, 69 (6), pp. 419-432.

[7] Burgers, W. P., C. W. L. Hill dan W. C. Kim (2008). " A Theory of Global Strategic Alliances: The Case of the Global Auto Industry”, Strategic management Journal, 14 (6), pp. 419-432.

[8] Burgelman, Robert A., Maidique, Modesto A., and Wheelwright, Steven C. (2006), Strategic Management of technology and Innovation, Third Edition, McGraw-Hill Irwin, New York, USA.

[9] Byrd et al., (2007), Perspective on Innovation, McGrw-Hill Irwin, New York, USA.

[10] Capon, N., and Glazer, N. (2007), Marketing and Technology: A Strategic Coaligment, Journal Marketing, Vol. 51, pp. 1-14.

[11] Chase, Richard B., Aquilano, Nicholas J., and Jacobs, F. Robert. (2006), Operation Management for Copetitive Advatage, Ninth Edition, McGraw-Hill Irwin, New York, USA.

[12] Chowdhury, Nuruddin A. H. M. (2010), Small and Medium Industries in Asian Developing Countries, Asian Development Review, Vol. 1, pp. 29-45.

[13] Connel, Lianne., Flynn, Andrew. (2009), The Environment, Innovation and Industry: A Case Study of South Wales, International Journal Technology Management, Vol. 17, No.5, pp. 481-493.

[14] Damanpour, fariborz, (2006), Organizational Innovation: A Meta-Analysis of Effect of Determinants and Moderators, Academy Management Journal, Vol. 34, No.3, pp. 555-590.

[15] Ettlie, John E., (2010), Managing Technological Innovation, John Wiley \& Sons, Inc., New York, USA.

[16] Freel, Mark s. (2008), Barriers to Product innovation in Small Manufacturing Firms, International Small Business Journal, Vol. 18, No. 2, pp. 60-80.

[17] Hair, Joseph F. Jr., Anderson, Rolph E., Tatham, Ronald L., and Black, William C. (2008), Multivariate Data Analysis, Fifth Edition, Prentice-Hall International, Inc. USA.

[18] Indriantoro, N., \& Supomo, B.(2006), Metodologi Penelitian Bisnis, BPFE, Yogyakarta.

[19] Khan A. M. and Manopichetwattama, V. (2009), Innovative and Non-innovative Small Firm: Types and Characteristics, Management Science, Vol. 35, pp. 597-606.

[20] Knight, Russel M. (2006), Breaking Down The Barriers, Business Quarterly, Autum, pp. 70-76.

[21] Kotler, Philip., (2004), Marketing Management, Pretice Hall Inc., New York, USA.

[22] Leonard, and Barton, D., (2005), Wellspings of Knowledge: Building and Sustaining the Sources of Innovation, Boston: Harvard Business School Press.

[23] Ravichandran, Thiruvenkatam. (2000), Redefening Organizational Innovation: Towards Theoretical Advancements, The Journal of High Technology management Research, Volume 10, Number 2, pp. 243-274.

[24] Rogers, Everett M., (2005), Diffusion of Innovations, Fouth Edition, The Free Press, New York, USA.

[25] Romjin, Henny., Albaladejo, Manuel (2001), Determinants of Innovation Capability in Small UK Firms: An Empirycal Analysis, QEH Working Paper Series QEHWPS40, Number 40. 
[26] Sasono, A. (2002),"Implementasi Kebijakan Tentang Lembaga Keuangan Konvensional dan Syariah Terhadap Kinerja UKM"' Makalah disampaikan pada seminar Sehari di Hotel Santika, Semarang 13 Jni 2002.

[27] Sekaran, Uma. (2000), Research Methods For Business, Third Edition, John Wiley \& Sons, Inc., New York, USA.

[28] Sharma, Subhash. (2006), Applied Multivariate techniques, John Wiley \& Sons, Inc., New York, USA.

[29] Siyamtinah, (2011), Model Peningkatan Kinerja Melalui Kapabilitas Inovasi Pada UKM di Semarang, Seminar Nasional Ilmu Ekonomi Terapan 251 Fakultas Ekonomi UNIMUS

[30] Slappendel, Carol. (2006), Perspective on Innovation in Organizations, Orgaization Studies, Vol. 17, No. 1, pp. 107-129.

[31] Swamidass, P.M. \& Newell, W.T. (2007), Manufacturing Strategy, Environmental Uncertainty and Performance: A Path Analytic Model, Management Science (33): $509-525$.

[32] Tidd, Joe., Bessant, John., Pavitt, Keith. (2007), Managing Innovation: Integrating Technological, Market and Organizational Change, John Wiley \& Sons, Inc., New York, USA.

[33] Tsai. W, MacMillan, I and M. Low (2006), "Effects of Strategy and Environment on Corporate Venture Succes in Industrial Markets, Journal of Business Venturing (6): $9-28$

[34] Undang-Undang Republik Indonesia Nomor 9 Tahun 1995 Tentang Usaha Kecil.

[35] Van de Ven, Adrew H., and Marshall, Scott P. (2009), Innonations and Organizations, Communication Research, Vol. 15, pp. 632-651.

[36] Wiklund, Johan (2009), The Sustainability of the Entrepreneurial Orientation, Performance Relationship, Entrepreneurship Theory and Practice (Fall):37 - 55. 